\title{
Effect of Tangerine Oil against Aspergillus niger Identified from Raw and Boron Treated Rubberwood
}

\author{
Sopa Jantamas, Narumol Matan, and Nirundorn Matan
}

\begin{abstract}
The antifungal efficacy of tangerine oil at various concentrations (10-200 $\mu \mathrm{L} / \mathrm{mL})$ were tested in agar medium and on rubberwood surface against Aspergillus niger indentified from raw and boron treated rubberwood. Various dilutions were made in methanol and vegetable oil was used as a control. Components of the tangerine oil were determined by means of gas chromatography-mass spectrometry (GC-MS) analysis. Minimum inhibitory concentrations (MICs) of tangerine oil against $A$. niger identified from raw and boron treated rubberwood in agar medium were $50 \mu \mathrm{L} / \mathrm{mL}$ and $180 \mu \mathrm{L} / \mathrm{mL}$, respectively. In addition, tangerine oil at those concentrations were capable of protecting against mold growth of $A$. niger on rubberwood surface for at least 12 weeks under storage condition at $25^{\circ} \mathrm{C}$ and $100 \%$ RH. Major constituents of tangerine oil identified were limonene $(69.2 \%)$, geranial $(16.4 \%)$, and p-cymene $(4.7 \%)$. Higher resistance to tangerine oil of $A$. niger identified from rubberwood treated with boron indicates that boron might enhance mold resistance of $A$. niger to essential oil.
\end{abstract}

Index Terms-Aspergillus niger, tangerine oil, boron, rubberwood, gas chromatography-mass spectrometry.

\section{INTRODUCTION}

Rubberwood is commonly used in several wood products such as indoor furniture and children toy. Nowadays, rubberwood is planted on a large scale in Southeast Asia. In Thailand, rubberwood plantation area has increased to about 634,570 Rai in the year 2012 [1]. Because of relatively low natural resistance, as a result rubberwood is susceptible to the attack of mold and fungi. Mold and mycotoxin contamination on rubberwood is one of the main factors that deteriorates the quality of the products. Specifically, Aspergillus niger is a dangerous mold for humans and was reported to be found on surface of rubberwood both before and after postharvest [2].

Boron compounds such as boric acid or borate are widely used in industries for rubberwood preservation against the attacks of bacteria, fungi and insects [3]. Boron compounds are colorless, odorless, non-corrosive and non-flammable [4]. However, because of their water solubility, boron compounds are easily leached out under outdoor exposure [5]. Furthermore, mold growth was observed on commercial kiln-dried rubberwood treated with boron.

Manuscript received March 24, 2013; revised May 7, 2013.

Sopa Jantamas and Nirundorn Matan are with Materials Science and Engineering, School of Engineering and Resources, Walailak University, Thasala, Nakhon Si Thammarat 80161, Thailand (e-mail: jsopa14@gmail.com; mnirundo@wu.ac.th).

Narumol Matan is with Food Science and Technology, School of Agricultural Technology, Walailak University,Thasala, Nakhon $\mathrm{Si}$ Thammarat 80160, Thailand (e-mail: nnarumol@wu.ac.th).
Alternatively, more environmentally friendly natural substances possessing antifungal activity such as essential oils should be investigated for rubberwood preservation. Tangerine oil is a well known aromatic and medicinal plant which is widely distributed in the Asia. Antifungal activity of tangerine oil against various molds has been reported by many researchers [6],[7]. However, there are limited studies that investigate the antifungal efficacy of tangerine oil on the commercial wood surface. The specific purpose of this study was to determine minimum inhibitory concentrations of tangerine oil against $A$. niger identified from raw and boron treated rubberwood both in agar medium and on rubberwood surface.

\section{MATERIALS AND METHODS}

\section{A. Preparation of Tangerine Oil Suspension}

The food-grade tangerine oil derived by steam distillation was provided by the Thai China Flavors \& Fragrances Industry Co., Ltd., Bangkok, Thailand. Tangerine oil solutions at concentrations of $12.5-200 \mu \mathrm{L} / \mathrm{mL}$ were prepared in methanol from pure tangerine oil by stirring for 10 minutes

\section{B. GC-MS Analysis}

GC-MS analysis was carried out on a gas chromatograph mass spectrometry (Hewlett-Packard Model 7890A, USA) equipped with a DB-5 column (J\&W Scientific, USA) at dimensions of $30 \mathrm{~cm} \times 0.25 \mathrm{~mm}$ ID and $0.25 \mu \mathrm{m}$ film thickness. The average helium carrier gas flow rate was $1 \mathrm{ml} / \mathrm{min}$; the split ratio of the column was $50: 1$ and the injector and detector temperatures were set at $250^{\circ} \mathrm{C}$ and $260^{\circ} \mathrm{C}$, respectively. The column oven temperature was held at $60^{\circ} \mathrm{C}$ for $30 \mathrm{sec}$, then programmed to $150^{\circ} \mathrm{C}$ at $40^{\circ} \mathrm{C} / \mathrm{min}$ and then to $260{ }^{\circ} \mathrm{C}$ at $2^{\circ} \mathrm{C} / \mathrm{min}$. Tangerine oil $(1.0 \mu \mathrm{l})$ was injected manually. Identification of the constituents was based on comparison of the retention times with those of authentic samples comparing their Kovats indices, and on computer matching with the NIST 08.L (database/ChemStation data system).

\section{Preparation of Inoculums}

Aspergillus niger WU 0713 and Aspergillus niger WU 0714 were identified from raw and boron treated kiln-dried rubberwood surfaces, respectively. Codes refer to strains held in the culture collection of the Wood Science and Engineering Research Unit of the Center for Scientific and Technological Equipment at Walailak University. Spores were obtained from mycelium grown on a malt extract agar (MEA; Merck Ltd, Thailand) medium at $25^{\circ} \mathrm{C}$ for 7 days and were collected by flooding the surface of the plates with $\sim 5$ $\mathrm{ml}$ sterile saline solution $(\mathrm{NaCl}, 8.5 \mathrm{~g} / 1$ water) containing 
Tween $80(0.1 \% \mathrm{v} / \mathrm{v})$. After counting the spores using a haemocytometer, the suspension was standardized to concentrations of $10^{6}$ spore/ $\mathrm{ml}$ by dilution with sterile water before using. The viability of all strains checked using quantitative colony counts were at $10^{6} \mathrm{CFU} / \mathrm{ml}$.

\section{Minimal Inhibitory Concentration (MIC)}

Determination of minimal inhibitory concentration (MIC) of the tangerine oil was performed by the agar dilution method in a Petri dish. Tangerine oil was added to the malt extract agar (MEA) at 10 to $200 \mu \mathrm{L} / \mathrm{mL}$. One hundred $\mu \mathrm{L}$ of spore suspension was then inoculated on the MEA. The vegetable oil was used as a control at the same concentration. The Petri dish was then incubated at $25^{\circ} \mathrm{C}$ for 3 days. Tests were performed in triplicate. The highest dilution (lowest concentration) showing no visible growth was regarded as the MIC.

\section{E. Preparation of Rubberwood}

Rubberwood specimens were prepared from freshly cut rubberwood lumber obtained from the plantation site in Nakhon Si Thammarat province, Thailand. The average moisture content of the rubberwood specimens before testing was $49 \pm 2 \%(n=10)$.

\section{F. Treatment of Rubberwood}

Sets of five random replicate rubberwood specimens $(7 \mathrm{~mm} \times 20 \mathrm{~mm}$ cross section by $70 \mathrm{~mm}$ long) were dip-treated for 10 minutes with tangerine oil suspensions $(200 \mu \mathrm{L} / \mathrm{mL}$, $100 \mu \mathrm{L} / \mathrm{mL}, 50 \mu \mathrm{L} / \mathrm{mL}, 25 \mu \mathrm{L} / \mathrm{mL}$ and $12.5 \mu \mathrm{l} / \mathrm{ml})$. Different dilutions of the substances were made with methanol. Pure vegetable oil was used as a control. Dip-treated specimens were held in a closed container overnight at room temperature before inoculation with spores of the test mold.

The dip-treated specimens were inoculated with $1 \mathrm{ml}$ of each mold-spore inoculum $\left(10^{6}\right.$ spores $\left./ \mathrm{ml}\right)$ and were incubated at $25^{\circ} \mathrm{C}$ with $100 \% \mathrm{RH}$ in an environmental chamber (Binder, Germany) for 12 weeks. The specimens were then individually rated for mold growth on a scale of 0 to 5 , with 0 denoting clean specimens and 5 representing heavy mold growth $(0=$ clean, $1=20 \%, 2=40 \%, 3=60 \%$, $4=80 \%, 5=100 \%$ of mold growth). The percentage of stain and mold (based on a control) for each essential oil concentration was calculated according to the percentage of inhibition (based on control $)=(\mathrm{A}-\mathrm{B} / \mathrm{A}) \times 100$, where $\mathrm{A}=$ total score for each mold at control, $\mathrm{B}=$ total score for each mold at each concentration of essential oil.

\section{RESULTS AND DisCUSSION}

\section{A. Tangerine Oil Compositions}

The chemical compositions of tangerine oil analyzed by GC-MS are shown in Table I. The major components of tangerine oil were limonene (69.2\%), geranial (16.4\%), and p-cymene $(4.7 \%)$. The results are in agreement with those published elsewhere [8-9] which reported that limonene was the major component of citrus oils including tangerine oil. Limonene was reported to inhibit growth of Aspergillus niger in agar medium [10]. In addition, geranial was reported to be use for inhibiting of Alternaria alternate, Aspergillus niger, Fusarium graminearum, Penicillium italicum, Rhizopus stolonifer, and Trichoderma spp. [11]. Antifungal activity of citrus oil was suggested to arsie from the synergistic activity of various compounds in citrus oil, rather than the activity of limonene alone [6], [12].

TABLE I: THE COMPOSITION OF TANGERINE OIL

\begin{tabular}{lll}
\hline & TABLE I: THE COMPOSITION OF TANGERINE OIL \\
\hline No. & Compound & Composition $(\%)$ \\
2 & Limonene & 69.2 \\
3 & Geranial & 16.4 \\
\hline
\end{tabular}

\section{B. MIC Testing}

Antimicrobial activity of tangerine oil at various concentrations against Aspergillus niger in agar medium is summarized in Table II.

TABLE II: MINIMAL INHIBITORY CONCENTRATIONS (MIC) OF TANGERIN OIL AGAINST ASPERGILLUS NIGER

\begin{tabular}{|c|c|c|c|c|}
\hline \multirow[t]{2}{*}{$\begin{array}{l}\text { Concentration } \\
(\mu \mathrm{L} / \mathrm{mL})\end{array}$} & \multicolumn{2}{|c|}{$\begin{array}{l}\text { Aspergillus niger WU } \\
0713 \text { (identified from raw } \\
\text { rubberwood) }\end{array}$} & \multicolumn{2}{|c|}{$\begin{array}{c}\text { Aspergillus niger WU } \\
0714 \text { (identified from } \\
\text { boron treated } \\
\text { rubberwood) }\end{array}$} \\
\hline & $\begin{array}{c}\text { Tangerine } \\
\text { oil }\end{array}$ & $\begin{array}{c}\text { Vegetable } \\
\text { oil }\end{array}$ & $\begin{array}{l}\text { Tangerine } \\
\text { oil }\end{array}$ & $\begin{array}{c}\text { Vegetable } \\
\text { oil }\end{array}$ \\
\hline 0 & + & + & + & + \\
\hline 10 & + & + & + & + \\
\hline 20 & + & + & + & + \\
\hline 30 & + & + & + & + \\
\hline 40 & + & + & + & + \\
\hline 50 & - & + & + & + \\
\hline 60 & - & + & + & + \\
\hline 70 & - & + & + & + \\
\hline 80 & - & + & + & + \\
\hline 90 & - & + & + & + \\
\hline 100 & - & + & + & + \\
\hline 120 & - & + & + & + \\
\hline 140 & - & + & + & + \\
\hline 160 & - & + & + & + \\
\hline 180 & - & + & - & + \\
\hline 200 & - & + & - & + \\
\hline
\end{tabular}

$+=$ Growth

- = Non-growth

According to the agar diffusion assay, $50 \mu \mathrm{l} / \mathrm{mL}$ of tangerine oil exhibited a significant effect against Aspergillus niger WU 0713 (indentified from raw rubberwood) with no mold growth on MEA. On the other hand, higher MIC of tangerine oil at $180 \mu \mathrm{l} / \mathrm{mL}$ was required for a complete inhibition of $A$. niger WU 0714 (indentified from boron treated rubberwood). It is clear that $A$. niger identified from the boron treated rubberwood was about 3.6 times stronger under tangerine oil treatment than one identified from raw rubberwood.

Boron was demonstrated to strongly inhibit spore germination, germ tube elongation, and mycelial spread of mold in the culture medium. Furthermore, boron can led to the leakage of cellular constituents which decreased mold decay. It may be directly related to the disruption effect of boron on cell membrane of the fungal pathogen that resulted 
in the breakdown of the cell membrane and loss of cytoplasmic materials from the hyphae [13]. However, it is shown in this work that boron has enhanced resistance of $A$. niger to tangerine oil as higher MIC of tangerine oil was required to inhibit $A$. niger identified from boron treated rubberwood with respect to one identified from raw rubberwood. Mechanisms underpinning an enhancement of A. niger resistance to tangerine oil of boron warrants further investigation.

\section{Mold test on Rubberwood}

Mold resistance levels of the treated rubberwood specimens inoculated with the test Aspergillus niger WU 0713 are shown in Fig. 1. The results are presented as the average rating of five specimens. Oil treatment might have some effects on moisture exclusion from the test specimens but the controls (treated with vegetable oil) reached a value of $100 \%$ mold coverage within four weeks. This suggests that tangerine oil at the MIC $(50 \mu \mathrm{L} / \mathrm{mL})$ was capable of inhibiting $A$. niger identified from raw rubberwood for at least 12 weeks under storage condition at $25^{\circ} \mathrm{C}$ and $100 \% \mathrm{RH}$.

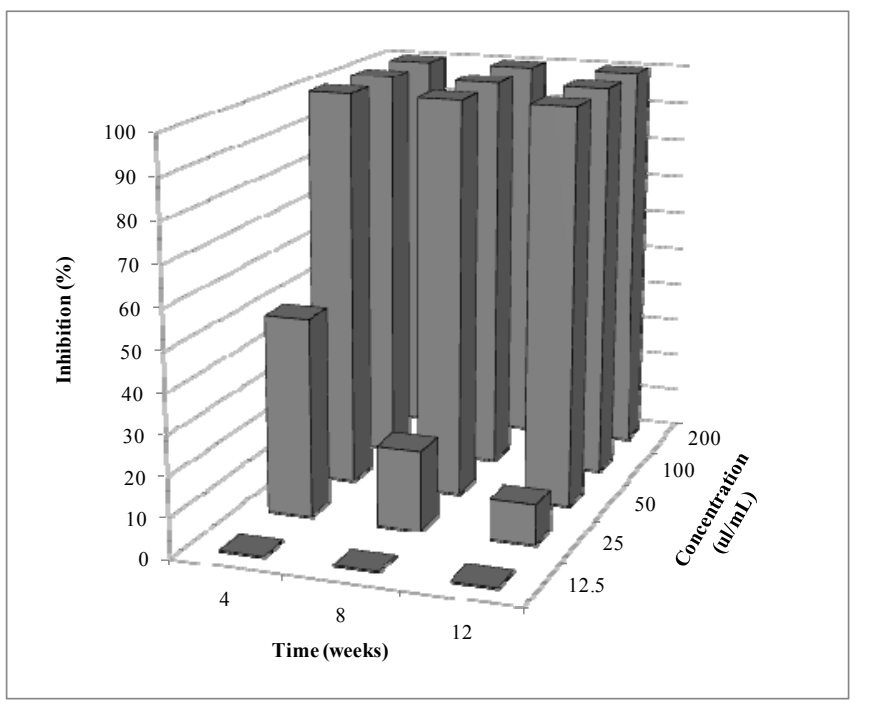

Fig. 1. Inhibition of Aspergillus niger WU 0713 identified from raw rubberwood by tangerine oil at various concentrations after 4,8 and 12 weeks of incubation at $25^{\circ} \mathrm{C}$ and $100 \% \mathrm{RH}$

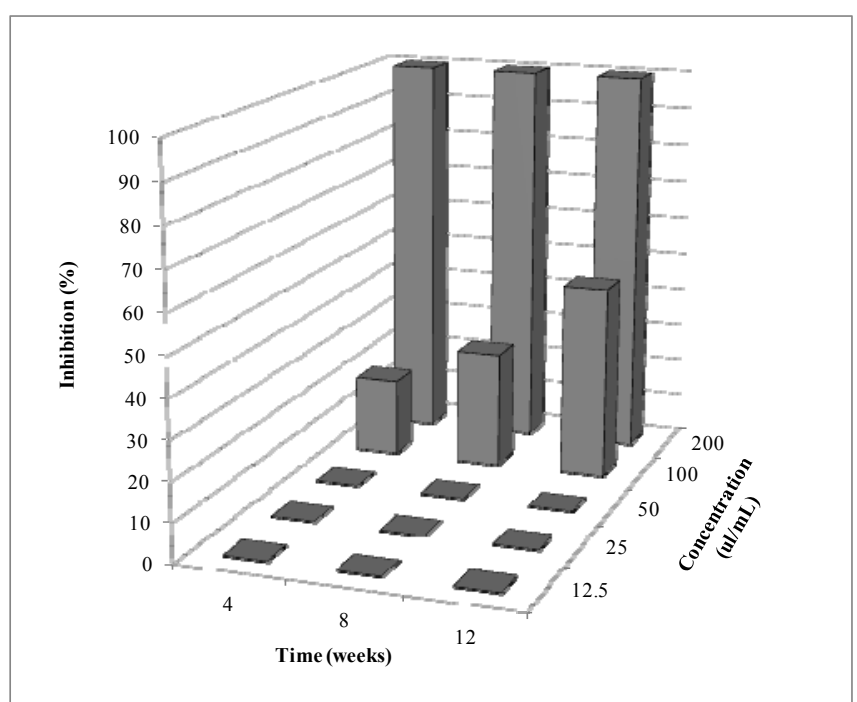

Fig. 2. Inhibition of Aspergillus niger WU 0714 identified from boron treated rubberwood by tangerine oil at various concentrations after 4,8 and 12 weeks of incubation at $25^{\circ} \mathrm{C}$ and $100 \% \mathrm{RH}$
On the other hand, to completely inhibit $A$. niger WU 0714 identified from rubberwood treated with boron, higher concentration of tangerine oil at $200 \mu \mathrm{l} / \mathrm{mL}$ was required. Lower concentrations of tangerine oil at $100 \mu \mathrm{l} / \mathrm{mL}$ also showed a degree of inhibition while tangerine oil at concentrations of lower than $50 \mu \mathrm{l} / \mathrm{mL}$ displayed no inhibitory effect with respect to the control treatments of vegetable oil (Fig. 2).

The results obtained were in agreement with those tested in agar medium. Similar concentrations of tangerine oil (50 $\mu \mathrm{L} / \mathrm{mL}$ and $200 \mu \mathrm{l} / \mathrm{mL}$ ) were required to inhibit $A$. niger identified from raw rubberwood and boron treated rubberwood, respectively, both in agar medium and on rubberwood surface.

Viuda-Martos [14] demonstrated that citrus essential oils such as orange, lemon, mandarin and grapefruit showed antifungal activity against $A$. niger, A. flavus, Penicillium chrysogenum and $P$. verrucosum. Orange oil is the most effective against $A$. niger, while mandarin is the best inhibitor of $A$. flavus. In the case of $P$. chrysogenum and $P$. verrucosum, grapefruit essential oil is the most effective growth reducer. In addition, Sartoratotto [15] reported the antifungal activities of essential oils from $O$. basilicum and its main component, linalool. Another important characteristic of the essential oils is their hydrophobicity which enables them to penetrate lipid components of microbial cell membrane and mitochondria, disrupting the cell structure and rendering them more permeable and resulting in leakage of critical molecules from within the cell and eventual death of the cells [16].

\section{CONCLUSIONS}

The results obtained in this study indicate that tangerine oil suspensions at $50 \mu \mathrm{L} / \mathrm{mL}$ and $200 \mu \mathrm{L} / \mathrm{mL}$ completely inhibited the Aspergillus niger identified from raw and boron treated rubberwood, respectively, on the surface of rubberwood for at least 12 weeks under storage condition at $25^{\circ} \mathrm{C}$ and $100 \% \mathrm{RH}$. It is suggested that tangerine oil can be used as a natural inhibitor to inactivate growth of $A$. niger on rubberwood surface. Enhancement of $A$. niger resistance to tangerine oil by boron is a subject that should be explored in the future.

\section{ACKNOWLEDGEMENTS}

This study was supported by the Wood Science and Engineering Research Unit, the Institute of Research and Development, Walailak University and the Thailand Research Fund (TRF)-Master Research Grants, Thailand.

\section{REFERENCES}

[1] OAE, (2011).Thailand Agriculture Statistics, Office of Agricultural Economics, Ministry of Agriculture and Cooperative. Available: http:// www2.oae.go.th/mis/Forecast/02_journal/forecast3-2555.pdf

[2] N. Matan, N. Matan, and S. Ketsa, "Effect of heat curing on antifungal activities of anise oil and garlic oil against Aspergillus niger on rubberwood," International Biodeterioration \& Biodegradation, vol.75, pp. 150-157, November 2012.

[3] J. D. Lloyd, "International borate status of borate preservative systems," in Proc. the second international conference on wood protection with diffusible preservatives and pesticides, pp. 45-54, 
1997.

[4] S. N. Kartal, T. Yoshimura, and Y. Imamura, "Decay and termite resistance of boron-treated and chemically modified wood by in situ co-polymerization of allyl glycidyl ether (AGE) with methylmethacrylate (MMA)," International Biodeterioration \& Biodegradation, vol. 53, pp. 111 - 117, March 2004.

[5] M. Korkmaz, "Boron: Environmental Exposure and Human Health," Encyclopedia of Environmental Health, 2011, pp. 442-445.

[6] N. Matan and N. Matan, "Antifungal activities of anise oil, lime oil and tangerine oil against molds on rubberwood (Hevea brasiliensis)," International Biodeterioration \& Biodegradation, vol. 62, no 1, pp. 75-78, July 2008.

[7] D. D. Costa Carvalho, E. Alves, R. Barbosa Camargos, D. Ferreira Oliveira, J. R. Soares Scolforo, D. A. de Carvalho, and T. R. Sâmia Batista, "Plant extracts to control Alternaria alternata in Murcott tangor fruits," Revista Iberoamericana de Micología, vol. 28, no 4, pp. 173-178, May 2011.

[8] L. Mondello, R. Shellie, A. Casilli, P. Q. Tranchida, P. Marriott, and G. Dugo, "Ultra-fast essential oil characterization by capillary GC on a $50 \mu \mathrm{m}$ ID column," Journal of Separation Science, vol. 27, pp. 699-702, June 2004.

S. M. Njoroge, H. N. Mungai, H. Koaze, N. T. L. Phi, and M. Sawamura, "Volatiles of mandarin (Citrus reticulate blanco) peel oil from Burundi," Journal of Essential Oil Research, vol. 18, no 6, pp. 659-662, 2006.

[9] V. Moleyar and P. Narasimham, "Antifungal activity of some essential oil components," Food Microbiology, vol. 3, no. 4, pp. 331-336, October 1986.

[10] R. Shukla, A. Kumar, P. Singh, and N. K. Dubey, "Efficacy of Lippia alba (Mill.) N.E. Brown essential oil and its monoterpene aldehyde constituents against fungi isolated from some edible legume seeds and aflatoxin B1 production," International Journal of Food Microbiology, vol. 135, no 2, pp. 165-170, October 2009.
[11] N. Sharma and A. Tripathi, "Fungitoxicity of the essential oil of Citrus sinensis on post-harvest pathogens," World Journal of Microbiology and Biotechnology, vol.22, pp. 587-593, June 2006.

[12] G. Qin, Y. Zong, Q. Chen, D. Hua, and S. Tian, "Inhibitory effect of boron against Botrytis cinerea on table grapes and its possible mechanisms of action," International Journal of Food Microbiology, vol.138, no, 1-2, pp. 145-150, March 2010.

[13] M. Viuda-Martos, Y. Ruiz-Navajas, J. Fernández-López, and J. Pérez-Álvarez, "Antifungal activity of lemon (Citrus lemon L.), mandarin (Citrus reticulata L.), grapefruit (Citrus paradisi L.) and orange (Citrus sinensis L.) essential oils. Food Control, vol. 19, no 12, pp. 1130-1138, December 2008.

[14] M. Serrano, D. Martinez-Romero, S. Castillo, F. Guillen, and D. Valero, "The use of the natural antifungal compounds improves the beneficial effect of MAP in sweet cherry storage," Innovative Food Science and Emerging Technologies. vol.6, no 1, pp. 115-123, March 2005.

[15] S. Burt, "Essential oils: their antibacterial properties and potential applications in foods - a review," International Journal of Food Microbiology, vol. 94, no 3, pp. 223-253, August 2009.

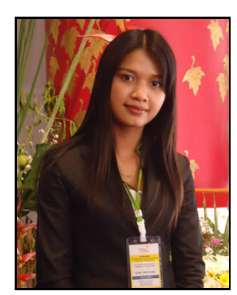

S. Jantamas was born in Nakhon Si Thammarat, Thailand in November, 1988. Jantamas was graduated from Chauat High School in 2006, then she was graduated from Prince of Songkla University, Department of Science with first degree in Biotechnology in 2010. Since then, Jantamas is working as a research assistant at Walailak University. Her master thesis is about application of natural oleoresin with essential against mold on rubberwood peeler core for a construction of log cabin. She is studying in master degree from 2012 until present. 